\title{
Growth performance and blood profile of gestating wad ewes fed dietary supplementation of ammonium sulphate \\ Ososanya ${ }^{1}$, T. O., Inyang, ${ }^{2}$ U. A. and Shehu, ${ }^{3}$ S. A. \\ ${ }^{1,3}$ Department of Animal science, University of Ibadan, Nigeria \\ ${ }^{2}$ Department of Animal science, University of Uyo, Nigeria \\ Corresponding Email: tososanya85@gmail.com
}

Abstract

The concern raised as a result of antibiotic usage in the livestock industry has necessitated the need for alternative feed additives such as ammonium sulphate. Hence, sixteen West African Dwarf (WAD) ewes averaging $24 \mathrm{~kg}$ in weight and aged eighteen months were used to determine the growth performance and blood chemistry of ammonium sulphate supplemented diets. The animals were divided into four groups of experimental diets consisting: D1 (0\%) (Control diet), D2 (0.25\%), D3 (0.50\%) and D4 (0.75\%) of ammonium sulphate (AMS) inclusion levels and were randomly allotted in a completely randomized design. They were also synchronized with prostaglandin $F_{2 a}$ and naturally mated with four (4) rams of proven fertility when they came on heat. Parameters determined were feed intake, dry matter intake (DMI), gestating weights and gains, and blood haematology and serum biochemistry such as white blood cells (WBC), red blood cell (RBC), packed cell volume $(P C V)$, haemoglobin $(H G B)$, albumin $(A)$, globulin $(G)$, total protein $(T P)$, cholesterol $(C H O L)$, blood urea nitrogen, creatinine $(C)$, alanine aminotransferase $(A L T)$, aspartate aminotransferase (AST) and alkaline phosphatase (ALP). The results showed that supplementing AMS in ewe diets generally enhanced $(p<0.05)$ final weight $(\mathrm{Kg})$, gestational weight gain $(\mathrm{Kg})$ and average daily weight gain $(\mathrm{g})$. The values ranged from $32.00-45.25$ $\mathrm{Kg} ; 8.25-22.25 \mathrm{Kg} ; 207.79-267.86 \mathrm{~g} / \mathrm{d}$ respectively. The feed conversion ratio improved with increasing levels of AMS with animals on D4 recording the least (0.20). Animals on D1 recorded the highest values for $P C V, H G B$, and $R B C$ while those on D3 had the least. The values were 44.25 and $41.00 \%$; 14.68 and $13.40 \mathrm{~g} / \mathrm{dl}$; and 13.02 and $11.86 \times 10^{6} / \mathrm{mm}^{3}$ respectively. Animals on D4 recorded the highest values for WBC $\left(5150.50 \times 10^{3} / \mathrm{mm}^{3}\right)$. Serum biochemical responses of pregnant sheep indicated significant differences $(p<0.05)$ of AMS supplementation on TP, A/G ratio, ALP and creatinine values. Animals on D1 recorded the highest values for $T P, A / G$ ratio; $A L T, B U N$ and $C$ while those on $D 2$ were least except for ALT where D 3 was least in ALT. The values were 8.68 and $8.15 \mathrm{~g} / \mathrm{dl} ; 0.80$ and 0.65 ; 289 and $235.50 \mathrm{I} . \mathrm{U} . / \mathrm{L} ; 10.75$ and $9.75 \mathrm{mg} / \mathrm{dl} ; 1.48$ and $1.08 \mathrm{mg} / \mathrm{dl}$ respectively. Animals on $D 2$ recorded the highest values for G, ALP and CHOL (4.80 mg/dl; $25.25 \mathrm{I} . \mathrm{U} / \mathrm{L}$; and 63.00 $\mathrm{mg} / \mathrm{dl}$ respectively). Inclusion of AMS improved conversion ratio thereby improving the performance of ewes and thus proved that it could be tolerated up to $0.75 \%$ supplementation in diets for ewes.

Keywords: Ewes, ammonium sulphate, haematology, serum, weight gain

\section{Introduction}

Non conventional feed resources available have been exploited for feeding livestock at all levels of production to make up for the shortages in conventional feedstuffs. Small ruminants (sheep and goats) in the humid zone of West Africa subsist on natural pastures and wastes which are high in fibre and lignin and low in crude protein contents (Aregheore, 2000). Ruminant nutritionists have long been interested in modulating the competition among different microbial populations with the objective of improving the efficiency of energy and protein 
utilization in the rumen. In evaluating other alternatives to ionophore antibiotics due to its reduced social acceptance (Stanton, 2013) in order to alter microbial population and modulate rumen fermentation feed additives has become a necessary option to achieve optimization of diet or feed formulations. Tham et al., (2008) reported that cassava leaf meal improved growth performance and feed conversion in cattle diets based on urea supplemented with rice straw. Urea is most common source of non protein nitrogen but the major problem is its rapid breakdown to ammonia in the rumen. Hence, there exists a need for feed supplement that allows the use of a higher proportion of non protein nitrogen in ruminant feed without the risk for ammonia toxicity. Rumen microorganisms can utilize inorganic sources of sulphur like ammonium sulphate which is a potential source of nitrogen and sulphur. It is more stable than urea for the release of ammonia (Firkins et al., 1986) as well as a protein supplement low in content of soluble protein and high in bypass protein (Leng, 2008). There are several potential benefits from using ammonium sulphate as alternative non protein nitrogen in the diets of ruminants which includes potentially higher microbial growth and efficiency as ATP is generated in the reduction of nitrate to ammonia and the nitrate can substitute fermentable nitrogen in a low protein diet. Information on effect of ammonium sulphate on non pregnant ewes are scanty, therefore, this study was conducted to evaluate the effect of ammonium sulphate supplementation on the performance and blood chemistry of pregnant ewes.

\section{Materials and methods}

The study location was the Sheep unit of Teaching and Research Farm, University of Ibadan, Oyo state, South West Nigeria. The location is between latitude $7.27^{\circ} \mathrm{N}$ and longitude $3.45^{\circ} \mathrm{E}$ and $200-300 \mathrm{~m}$ above sea level. Found in the tropical rainforest zone, the daily temperature and humidity are within the ranges of $25^{\circ} \mathrm{C}-32^{\circ} \mathrm{C}$ and 55 $\%-75 \%$ respectively depending on the season. The total annual rainfall ranges between $2032 \mathrm{~mm}$ - $3048 \mathrm{~mm}$ with a bimodal rainfall pattern that begins in late March and ends in late October.

The animals were housed individually in cleaned, disinfected pens having wood shavings spread on the floor as bedding material. A total of 16 dry ewes (West African Dwarf breed) were used together with 4 rams of proven fertility. The ewes aged 18 months and the rams above 18 months with initial average weight of 24.00 $\mathrm{kg}$. Each treatment comprised four replicates and one ram was introduced into each treatment to run for one week through natural mating after synchronization of ewes with prostaglandin $\mathrm{F}_{2 a}$.

Animals were treated with ivermectin super administered subcutaneously against ectoparasites and endoparasites which was repeated two weeks after. Long acting oxytetracycline (antibiotic) was also administered intramuscularly against bacterial infections. Animals were weighed before the commencement of the study and served with experimental diets in feed troughs at $5 \%$ body weight on dry matter basis of concentrate and guinea grass (Panicum maximum). They were fed once a day at $0800 \mathrm{~h}$. Feed intake was recorded daily and it lasted for 170 days including 15 days of acclimatization to period of last lamb was delivered.. Clean water and salt licks were also served throughout the study period.

Ammonium sulphate used as supplement in diet contained Iron $(\mathrm{Fe}) 0.001 \%$, Arsenic (As) $0.0005 \%$, loss on drying at $1.50^{\circ} \mathrm{C}$ $(1 \%)$, residue of ignition $\left(\mathrm{SO}_{4}\right)(0.05 \%)$, 
lead $(\mathrm{Pb})(0.001 \%)$, nitrate $\left(\mathrm{NO}_{3}\right) 0.002 \%$, chloride $(\mathrm{Cl}) \quad 0.002 \%, \mathrm{pH} 5 \%$ solution $\left(20^{\circ} \mathrm{C}\right)(4.50-6.00)$, Assay on dried substance $(98.50 \%)$.

Feed ingredients were ground, as shown in Table 1, before mixing to make a total mix ration (TMR) with 50:50 concentrate to roughage ratio without supplementation (Control/T1) and TMR with $0.25 \%$ (T2), $0.50 \%$ (T3) and $0.75 \%$ (T4) ammonium sulphate respectively.
Oestrus was synchronized in all the dry ewes with prostaglandin $\mathrm{F}_{2 \alpha}$ and observed closely. Rams were introduced $24 \mathrm{~h}$ post injection of prostaglandin $\mathrm{F}_{2 \alpha}$ and allowed to run with the ewes for 7 days. All ewes were weighed before mating and weekly until parturition after which weekly weight gain of ewes were recorded accordingly. Data generated included body weight gain in gestation $(\mathrm{Kg})$, average daily gain $(\mathrm{g} / \mathrm{d})$ and feed conversion efficiency.

Table 1: Gross composition (\%) of concentrate

\begin{tabular}{lllll}
\hline Ingredients & T1 & T2 & T3 & T4 \\
\hline Ammonium sulphate & 0.00 & 0.25 & 0.50 & 0.75 \\
Urea & 1.00 & 1.00 & 1.00 & 1.00 \\
Dry cassava peel & 60.00 & 60.00 & 60.00 & 60.00 \\
Brewers dry grain & 23.00 & 23.00 & 23.00 & 23.00 \\
Palm kernel cake & 10.00 & 10.00 & 10.00 & 10.00 \\
Dicalcium phosphate & 1.00 & 1.00 & 1.00 & 1.00 \\
Oyster shell & 2.00 & 2.00 & 2.00 & 2.00 \\
Salt & 2.00 & 2.00 & 2.00 & 2.00 \\
Premix (growers) & 1.00 & 1.00 & 1.00 & 1.00 \\
Total & 100.00 & 100.25 & 100.50 & 100.75 \\
Calculated CP \% & 8.42 & 8.46 & 8.50 & 8.54 \\
\hline
\end{tabular}

On day $175,5 \mathrm{ml}$ of blood samples were collected from each experimental animal according to standard procedures for haematology and serum biochemical analyses. Blood samples were determined for packed cell volume (PCV) and ha emoglobin (HGB) using microhaematocrit method and cyanmethaemoglobin method respectively (Schalm et al., 1975). Erythrocyte count (RBC) and leucocyte count (WBC) were determined using improved Neubauer haemocytometer after appropriate dilution (Schalm et al., 1975). The mean corpuscular haemoglobin (MCH), mean corpuscular volume (MCV) and mean corpuscular haemoglobin concentration (MCHC) were calculated. Serum urea was determined by urease method and creatinine by Folin-wu filtrate methods
(Toro and Ackerman, 1975). Serum total protein was determined by Biuret method (Kohn and Allen, 1995), while albumin was determined using the bromocresol (BCG) method (Peter et al., 1982). Serum cholesterol was measured using appropriate laboratory kits (Gowenlock, 1988), aspartate amino tranferase (AST), alanine amino transferase (ALT) and alkaline phosphatise (ALP) activities were determined using spectrophotometric methods (McComb et al., 1988; Rej and Hodder, 1983).

Total mix ration (TMR) samples comprising 50:50 concentrate to roughage ratio were dried in a hot air oven at $105^{\circ} \mathrm{C}$ for $24 \mathrm{~h}$ and ground to pass through a $1 \mathrm{~mm}$ screen. Dry matter (DM), organic matter $(\mathrm{OM})$, crude protein $(\mathrm{CP})$ and ether extract (EE) were analysed according to AOAC 
(1990). The acid detergent fibre (ADF), acid detergent lignin (ADL) and neutral detergent fibre (NDF) were analysed by the method of Van Soest et al., (1991).

Data collected were subjected to one way analysis of variance according to the procedures of Statistical Analysis System (SAS, 1999) to determine the significance of treatment effects on the various parameters measured and where differences were observed, the means separated using Duncan Multiple Range Test of the same package.

\section{Result and discussion}

\section{Chemical composition}

Table 2 reveals the chemical composition of ammonium sulphate supplemented diets fed to pregnant WAD ewes. The dry matter ranged from $82.50 \%$ to $88.30 \%$. The crude protein content $(\%)$ fell within the range of $8.60-9.21 \%$. The fibre fractions (NDF, ADF and ADL) ranged between 52.93\% $55.37 \%, 31.18 \%-31.84 \%$ and $19.67 \%$ $20.02 \%$ respectively.

The content of crude protein $(\mathrm{CP})$ in the diets was higher than $7.00 \% \mathrm{CP}$ recommended being minimum requirement for ruminants in the tropics (NRC, 1981) but below the range for minimum protein requirement of $10-12 \%$ recommended by ARC (1985) for ruminants. The CP range was higher than the requirements for ewes for first 15 weeks of gestation $(8.02 \%)$ and low for last 6 weeks of gestation $(9.80 \%)$ for ewes weighing $20 \mathrm{Kg}$ (Ranjhan, 2001).

Table 2: Proximate composition and fibre fractions of ammonium sulphate supplemented TMR fed to pregnant WAD ewes

\begin{tabular}{llllll}
\hline Parameter & T1 & T2 & T3 & T4 & SEM \\
\hline Dry matter & 86.50 & 82.50 & 85.80 & 88.30 & 2.13 \\
Crude protein & 8.60 & 9.00 & 9.10 & 9.21 & 0.17 \\
Crude fibre & 10.20 & 11.90 & 12.00 & 11.60 & 0.24 \\
Ether extract & 9.80 & 9.50 & 10.10 & 10.10 & 0.21 \\
Ash & 12.80 & 12.80 & 12.59 & 12.88 & 0.25 \\
Nitrogen free extract & 59.00 & 56.20 & 52.40 & 56.75 & 1.32 \\
Neutral detergent fibre & 52.93 & 55.37 & 55.23 & 55.22 & 1.25 \\
Acid detergent fibre & 31.63 & 31.51 & 31.84 & 31.18 & 0.12 \\
Acid detergent lignin & 19.67 & 20.02 & 19.98 & 19.70 & 0.08 \\
\hline
\end{tabular}

T1: 0.00\% AMS; T2: 0.25\% AMS; T3: 0.50\% AMS; T4: 0.75\% AMS

\section{Haematology}

The haematological profile of pregnant WAD ewes fed ammonium sulphate supplemented diets and Panicum maximum are presented in Table 3. The packed cell volume (PCV) ranged from $41.00 \%$ in $\mathrm{T} 3$ to $44.25 \%$ in $\mathrm{T} 1$. The haemoglobin (HGB) fell within the range of $13.40 \mathrm{~g} / \mathrm{dl}(\mathrm{T} 3)-14.68$ $\mathrm{g} / \mathrm{dl}$ (T1). Red blood cell (RBC) and neutrophil $(\mathrm{N})$ also followed the same pattern as in PCV and HGB with the following value ranges: $11.86-13.02 \mathrm{x}$ $10 \% \mathrm{~mm}^{3}$ and $23.00-31.00 \%$, respectively.
The white blood cell (WBC) ranged from $4312.50 \times 10^{3} / \mathrm{mm}^{3}$ in $\mathrm{T} 2$ to $5150.50 \mathrm{x}$ $10^{3} / \mathrm{mm}^{3}$ in T4. Significant effects of the supplement were observed for platelets, $\mathrm{MCH}$ and MCHC. The MCH refers to the average haemoglobin content of a single $\mathrm{RBC}$ while $\mathrm{MCHC}$ is reliable for establishing iron deficiency in animals. The values obtained in this study were within the physiological range of animals said to be normochromic/normocytic condition (Mitruka and Rawnsley, 1977).

The PCV value obtained in this report was 


\section{Ososanya, Inyang and Shehu}

higher than that reported by Mitruka and Rawnsley (1977) who reported 31.50 $36.70 \%$ for female Dorset-Delane adult sheep weighing 40-60 Kg. This difference could be due to differences in breed, nutrition and physiological status (Onifade et al., 1999). The varying levels of ammonium sulphate had no significant effect on haematological indices such as RBC, WBC, HGB, lymphocytes, neutrophils, and MCV.

Table 3: Haematological parameters of pregnant WAD ewes fed ammonium sulphate supplemented TMR

\begin{tabular}{llllll}
\hline Indices & T1 & T2 & T3 & T4 & SEM \\
\hline PCV (\%) & 44.25 & 42.00 & 41.00 & 43.50 & 1.19 \\
HGB $(\mathrm{g} / \mathrm{dl})$ & 14.68 & 14.00 & 13.40 & 14.45 & 0.40 \\
RBC x 10 $/ \mathrm{mm}^{3}$ & 13.02 & 12.34 & 11.86 & 12.81 & 0.24 \\
WBC x 10/mm & 4767.50 & 4312.50 & 4550.50 & 5150.50 & 182.05 \\
Platelets (\%) & $68675^{\mathrm{b}}$ & $99250^{\mathrm{a}}$ & $81250^{\mathrm{ab}}$ & $95000^{\mathrm{ab}}$ & 0.43 \\
Lymphocytes (\%) & 67.75 & 68.00 & 72.75 & 66.00 & 1.34 \\
Neutrophils (\%) & 31.00 & 27.25 & 23.00 & 29.00 & 1.51 \\
MCV $\left(\mu^{3}\right)$ & 33.95 & 34.06 & 34.53 & 33.90 & 0.44 \\
MCH $(\mu \mathrm{g})$ & $33.17^{\mathrm{ab}}$ & $33.54^{\mathrm{a}}$ & $32.70^{\mathrm{b}}$ & $33.23^{\mathrm{ab}}$ & 0.10 \\
MCHC (\%) & $33.18^{\mathrm{ab}}$ & $33.33^{\mathrm{a}}$ & $32.68^{\mathrm{ab}}$ & $33.22^{\mathrm{b}}$ & 0.11 \\
\hline a,b,c means with different superscripts in the same row differ significantly $(\mathrm{p}<0.05)$ & \\
T1: $0.00 \%$ AMS; T2: $0.25 \%$ AMS; T3: 0.50\% AMS; T4: 0.75\% AMS &
\end{tabular}

\section{Serum biochemical indices}

Serum biochemical responses of pregnant ewes fed ammonium sulphate supplemented diets are presented in Table 4. The total protein (TP) ranged from $8.15 \mathrm{~g} / \mathrm{dl}$ in $\mathrm{T} 2$ to $8.68 \mathrm{~g} / \mathrm{dl}$ in $\mathrm{T} 1$. There was significant effect of treatment on TP. However, animals on Control (T1) were higher numerically than those on ammonium sulphate supplemented diets. Albumin (A) and globulin (G) ranged from $3.33 \mathrm{~g} / \mathrm{dl}$ to $3.63 \mathrm{~g} / \mathrm{dl}$ and $4.38 \mathrm{mg} / \mathrm{dl}$ to 4.80 $\mathrm{mg} / \mathrm{dl}$ respectively. The A:G ratio which ranged from 0.65 in $\mathrm{T} 2$ to 0.80 in $\mathrm{T} 1$ showed significant difference. The liver enzymes (AST, ALP and ALT) ranged from 76.25 $\mathrm{IU} / \mathrm{L}-108.00 \mathrm{IU} / \mathrm{L}, 10.25 \mathrm{IU} / \mathrm{L}-25.25$ $\mathrm{IU} / \mathrm{L}$ and $235.50 \mathrm{IU} / \mathrm{L}-289.25 \mathrm{IU} / \mathrm{L}$ respectively. Except for ALT, other liver enzymes showed significant effect of treatment. Blood urea nitrogen (BUN) ranged between $9.75 \mathrm{mg} / \mathrm{dl}$ and 10.75 $\mathrm{mg} / \mathrm{dl}$. Creatinine (C) and cholesterol (CHOL) ranged from $1.08 \mathrm{mg} / \mathrm{dl}$ to 1.48 $\mathrm{mg} / \mathrm{dl}$ and $57.75 \mathrm{mg} / \mathrm{dl}$ to $63.00 \mathrm{mg} / \mathrm{dl}$ respectively. Animals on T3 and T4 recorded lower values for $\mathrm{C}$ and $\mathrm{CHOL}$ when compared with $\mathrm{T} 1$ and T2. Significant difference was observed in creatinine implying that there was wastage of muscle energy especially for animals on $\mathrm{T} 2$ and foetus growth effect.

The values for TP, albumin, globulin, $\mathrm{A} / \mathrm{G}$, AST, C and CHOL reported in this study were within the range documented by Mitruka and Rawnsley (1977) for normal healthy sheep while ALP and BUN were below normal levels and ALT was far above normal level (Mitruka and Rawnsley, 1977). The decrease in blood protein fractions (TP, A and G) could be attributed to the increase in foetus weight (Abdel Rahman et al., 2012), low digestibility (Abdel-Khalek et al., 2000) and low urea concentrations.. Eissa et al., (1992) had reported that serum AST and ALT concentrations increased with pregnancy progress of ewes and cows. This increased 
activity of ALT may be due to more production(Vihan and Rai, 1987). requirements of amino acids during milk

Table 4: Serum biochemical responses of pregnant ewes fed ammonium sulphate supplemented TMR

\begin{tabular}{llllll}
\hline Indices & T1 & T2 & T3 & T4 & SEM \\
\hline Total protein (g/dL) & $8.68^{\mathrm{a}}$ & $8.15^{\mathrm{b}}$ & $8.50^{\mathrm{ab}}$ & $8.55^{\mathrm{ab}}$ & 0.07 \\
Albumin (g/dL) & 3.63 & 3.33 & 3.60 & 3.63 & 0.06 \\
Globulin (mg/dL) & 4.38 & 4.80 & 4.75 & 4.68 & 0.08 \\
A:G & $0.80^{\mathrm{a}}$ & $0.65^{\mathrm{b}}$ & $0.70^{\mathrm{ab}}$ & $0.70^{\mathrm{ab}}$ & 0.02 \\
AST (IU/L) & $103.75^{\mathrm{a}}$ & $76.25^{\mathrm{b}}$ & $77.50^{\mathrm{b}}$ & $108.00^{\mathrm{a}}$ & 13.45 \\
ALP (IU/L) & $12.75^{\mathrm{b}}$ & $25.25^{\mathrm{a}}$ & $10.25^{\mathrm{b}}$ & $24.75^{\mathrm{a}}$ & 1.37 \\
ALT (IU/L) & 289.25 & 283.75 & 235.50 & 269.00 & 14.91 \\
BUN (mg/dL) & 10.75 & 9.75 & 10.00 & 10.00 & 0.20 \\
Creatinine (mg/dL) & $1.48^{\mathrm{a}}$ & $1.08^{\mathrm{b}}$ & $1.20^{\mathrm{ab}}$ & $1.35^{\mathrm{ab}}$ & 0.05 \\
Cholesterol (mg/dL) & 61.75 & 63.00 & 57.75 & 59.50 & 1.42 \\
\hline
\end{tabular}

${ }_{a, b, c}$ means with different superscripts in the same row differ significantly $(p<0.05)$

T1: 0.00\% AMS; T2: 0.25\% AMS; T3: 0.50\% AMS; T4: 0.75\% AMS

Gestational weights of experimental ewes

The gestational weights $(\mathrm{Kg})$ of the ewes over a period of 22 weeks are presented in Table 5. The weights increased successively until the last week from an initial weight of $23.75 \mathrm{Kg}, 23.25 \mathrm{Kg}, 25.50 \mathrm{Kg}$ and $23.00 \mathrm{Kg}$ to $32.00 \mathrm{Kg}, 32.00 \mathrm{Kg}, 34.50 \mathrm{Kg}$, and $45.25 \mathrm{Kg}$ respectively for $\mathrm{T} 1, \mathrm{~T} 2, \mathrm{~T} 3$, and T4. Significant effect was observed in weeks 1,9 and 22 . The animals on ammonium sulphate supplemented diets (T3 and T4) performed better than control (T1) in most of the weeks except for weeks 2, 5 and 8 . The result shows that supplementation of ewes diets with ammonium sulphate improved the gestation weekly weights considerably. Thus, it proved that it can be regarded as a source of non-protein nitrogen and sulphur for body cell and tissue development.

\section{Performance of ewes}

The performance characteristics of WAD ewes fed dietary supplementation of ammonium sulphate are shown in Table 6. Initial weights of ewes ranged from 23.00 $\mathrm{kg}$ in $\mathrm{T} 4$ to $25.50 \mathrm{Kg}$ in $\mathrm{T} 3$. The final weights ranged from $32.00 \mathrm{Kg}$ in $\mathrm{T} 1$ and $\mathrm{T} 2$ to $45.25 \mathrm{Kg}$ in $\mathrm{T} 4$. Final weight $(\mathrm{Kg})$ of animals on T4 were significantly different $(p<0.05)$ when compared with others. However, the average daily dry matter intake (Kg DM) ranged from $4.13 \mathrm{Kg}$ (T2) to $4.42 \mathrm{Kg}$ (T4). The gestational weight gain $(\mathrm{Kg})$ for animals on $\mathrm{T} 4(22.25 \mathrm{Kg})$ was highest $(\mathrm{p}<0.05)$ while those on T1 and T2 were the lowest ( $8.25 \mathrm{Kg}$ respectively). The average daily weight gain $(\mathrm{g} / \mathrm{d})$ ranged from $207.79 \mathrm{~g} / \mathrm{d}$ in T1 to $267.86 \mathrm{~g} / \mathrm{d}$ in T4. The feed conversion ratio was lowest $(0.20)$ in animals on $\mathrm{T} 4$ and higher for those on $\mathrm{T} 1$ (0.53).

Tisdale (1977) reported that protein synthesis from addition of the following inorganic sources decreased in the following order: $\left(\mathrm{NH}_{4}\right) \mathrm{SO}_{4}>\mathrm{S}>\mathrm{Na}_{2} \mathrm{SO}_{4}>$ $\mathrm{K}_{2} \mathrm{SO}_{4}>\mathrm{CaSO}_{4}>\mathrm{Mg} \mathrm{\textrm {SO } _ { 4 }}$. Ammonium sulphate and elemental sulphur were therefore the most effective in promoting the synthesis of rumen microbial protein and certain volatile fatty acids. Both nitrogen and sulphur supplementation are noted to improve performance by enhancing bacterial protein synthesis in the rumen and amino acids balance (Morrison etal., 1990). 
Ososanya, Inyang and Shehu

Table 5: Gestational weights of experimental ewes

\begin{tabular}{llllll}
\hline Week & T1 & T2 & T3 & T4 & SEM \\
\hline 1 & $23.75^{\mathrm{ab}}$ & $23.25^{\mathrm{ab}}$ & $25.50^{\mathrm{a}}$ & $23.00^{\mathrm{b}}$ & 0.98 \\
2 & 26.50 & 26.50 & 26.25 & 26.00 & 0.87 \\
3 & 22.75 & 23.00 & 23.75 & 27.50 & 0.99 \\
4 & 26.50 & 26.50 & 28.25 & 27.75 & 1.35 \\
5 & 27.75 & 26.00 & 27.00 & 27.00 & 1.29 \\
6 & 27.50 & 28.25 & 29.50 & 29.00 & 0.89 \\
7 & 28.00 & 26.50 & 28.25 & 30.00 & 0.79 \\
8 & 29.00 & 26.75 & 28.50 & 32.00 & 0.92 \\
9 & $27.50^{\mathrm{b}}$ & $29.50^{\mathrm{ab}}$ & $31.00^{\mathrm{ab}}$ & $33.25^{\mathrm{a}}$ & 0.81 \\
10 & 29.75 & 30.75 & 31.50 & 34.25 & 0.84 \\
11 & 30.25 & 29.25 & 31.50 & 34.75 & 0.97 \\
12 & 30.50 & 31.00 & 34.00 & 35.50 & 1.09 \\
13 & 30.75 & 31.50 & 34.50 & 35.75 & 1.06 \\
14 & 31.50 & 31.75 & 34.50 & 36.25 & 1.39 \\
15 & 32.50 & 31.75 & 35.00 & 38.50 & 1.31 \\
16 & 32.13 & 33.00 & 36.00 & 40.50 & 1.44 \\
17 & 32.00 & 33.25 & 36.25 & 40.50 & 1.42 \\
18 & 32.00 & 33.25 & 36.25 & 38.25 & 1.42 \\
19 & 31.75 & 31.50 & 35.25 & 38.25 & 1.32 \\
20 & 32.75 & 32.25 & 36.00 & 40.25 & 1.45 \\
21 & 32.50 & 33.25 & 35.00 & 40.75 & 1.49 \\
22 & $32.00^{\mathrm{b}}$ & $32.00^{\mathrm{b}}$ & $34.50^{\mathrm{ab}}$ & $45.25^{\mathrm{a}}$ & 1.29 \\
\hline a,b & means with different superscripts in the same row differ significantly $(\mathrm{p}<0.05)$ \\
T1: $0.00 \%$ AMS; T2: $0.25 \%$ AMS; T3: $0.50 \%$ AMS; T4: $0.75 \%$ AMS & \\
& & & &
\end{tabular}

Table 6: Performance characteristics of WAD ewes fed dietary supplementation of ammonium sulphate

\begin{tabular}{llllll}
\hline Parameter & T1 & T2 & T3 & T4 & SEM \\
\hline Initial weight $(\mathrm{Kg})$ & $23.75^{\mathrm{ab}}$ & $23.25^{\mathrm{ab}}$ & $25.50^{\mathrm{a}}$ & $23.00^{\mathrm{b}}$ & 0.98 \\
Final weight $(\mathrm{Kg})$ & $32.00^{\mathrm{b}}$ & $32.00^{\mathrm{b}}$ & $34.50^{\mathrm{b}}$ & $45.25^{\mathrm{a}}$ & 0.31 \\
Gestational weight gain $(\mathrm{Kg})$ & $8.25^{\mathrm{b}}$ & $8.25^{\mathrm{b}}$ & $9.00^{\mathrm{b}}$ & $22.25^{\mathrm{a}}$ & 0.14 \\
Average daily weight gain $(\mathrm{g} / \mathrm{d})$ & $207.79^{\mathrm{c}}$ & $207.79^{\mathrm{c}}$ & $224.03^{\mathrm{b}}$ & $267.86^{\mathrm{a}}$ & 0.25 \\
Total feed intake $(\mathrm{kg})$ & $668.82^{\mathrm{b}}$ & $636.02^{\mathrm{c}}$ & $660.66^{\mathrm{b}}$ & $680.68^{\mathrm{a}}$ & 0.21 \\
Average feed intake $(\mathrm{Kg} / \mathrm{d})$ & $4.33^{\mathrm{b}}$ & $4.13^{\mathrm{c}}$ & $4.29^{\mathrm{b}}$ & $4.42^{\mathrm{a}}$ & 0.12 \\
Feed conversion ratio & $0.53^{\mathrm{a}}$ & $0.50^{\mathrm{a}}$ & $0.48^{\mathrm{a}}$ & $0.20^{\mathrm{b}}$ & 0.17 \\
\hline
\end{tabular}

${ }_{\mathrm{a}, \mathrm{b}, \mathrm{c}}$ means with different superscripts in the same row differ significantly $(\mathrm{p}<0.05)$

T1: $0.00 \%$ AMS; T2: 0.25\% AMS; T3: 0.50\% AMS; T4: 0.75\% AMS

\section{Conclusion}

Supplementation of pregnant ewe diet with ammonium sulphate indicated its effect on total protein, albumin/globulin ratio, AST, ALP and creatinine. In addition, ammonium sulphate supplementation gave the highest dry matter intake and gestational weight gain especially at $0.75 \%$ inclusion level. However, since its supplementation produced no deleterious effects in the studied animals, ammonium sulphate is recommended for inclusion in ruminant diets especially at $0.75 \%$. 
Growth performance and blood profile of gestating wad ewes fed dietary supplementation of ammonium sulphate

\section{References}

Abdel-Khalek, A. E., Mehrez, A. F. and Omar, E. A. 2000. Effect of yeast culture (Lacto-Sacc) on rumen activity, blood constituents and growth of suckling Friesian calves. Proc. Conf. Anim. Prod. In the 21st Century, Sakha, 18-20 April 2000: 201-210.

Abdel Rahman, H., Baraghit, G. A., Abu El-Ella, A. A., Omar, S. S., Abo Ammo, F. F. and Kommona, O. F. 2012. Physiological responses of sheep to diet supplementation with yeast culture. Egyptian Journal of Sheep \& Goat Sciences. 7: 27-38.

A.O.A.C. 1990. Official methods of analysis $15^{\text {th }}$ ed. Association of Analytical Chemist. Washington DC. Pp. 69-88.

A. R. C. 1985. Agricultural Research Council. The nutrient requirements of farm animals. No. 2, Ruminants: Tech. Rev. and Summaries. ARC, London.

Aregheore, E.M. 2000. Chemical composition and nutritive value of some tropical by-product feedstuffs for small ruminants-in vivo and in vitro digestibility. Anim. Feed Sci. Technol., 85: 99-109.

Cooper, G. R. and McDaniel, V. 1970. Standard method in serum enzyme activity. Clinical Chemistry 6: 159

Eissa, N. A., Allam, F. M. and Elyas, A. H. 1992. Changes in some blood parameters around calving in cows and buffaloes. Beni-Suef. Vet. Med. Res., 2(2): 45-49.

Firkins, J. L., Berger, L. L., Merchen, N. R., Farhez, Jr., G. C. 1986. Effects of forage particle size, level of feed intake and supplemented protein, degradability on microbial protein synthesis and site of nutrient digestion in steers. J. Anim. Sci. 62: $1081-1094$.

Gowenlock, A. H. 1988. Varelys Practical Clinical Biochemistry. 6 edn. Heinemann Medical Books, 22 Bedford square, London WCIB HH.

Kohn, R. A. and Allen, M. S. 1995. Enrichment of proteolytic activity relative to nitrogen in preparation from the rumen for in vitro studies. Anim. Feed Sci. and Technol. 52: 114.

Leng, R. A. 2008. Decline in available world resources implications for livestock production systems in Asia. Livestock research rural d e v e 1 o p m e n t . $2008 ; 20$ Article8.http://www.cipav.org.co/lr rd/lrrd20/1/leng2008.htm.

McComb, R. B., Bowers, G. N. and Rosen, S. 1988. Alkaline phosphatise. Plenum Press, New York.

Mitruka, B. M. and Rawnsley, H. M. 1977. Clinical Biochemical and Haematological Reference Values in normal experimental animals, Masson Publishing, USA, Inc. pp: 42-58.

Morrison, M., Murray, R. M. and Boniface, A. N. 1990. Nutrient metabolism and rumen microorganisms in sheep fed poor quality tropical grass hay supplemented with sulphate J. Agric. Sci. 115: 269275.

NRC - National Research Council. 1981. National Research Council. Nutrient Requirement of Domestic Animals. Nutrient Requirements of Sheep. National Academy of Science, Washington, D.C., USA.

Onifade, A. A., Obiyan, R. I., Onipede, E., Adejumo, D. O., Abu, O.A. and B abatunde, G. M. 1999 . 


\section{Ososanya, Inyang and Shehu}

Assessment of the effects of supplementing rabbits with a culture of Saccharomyces cerevisiae using growth performance, blood composition and clinical enzymes activities. Anim. Feed Sci. and Tech. . 77: $25-32$.

Peter, T., Biamonte, G. T. and Doumas, B. T. 1982. Protein (total protein) in serum, urine and cerebrospinal fluid: albumin in serum. In: selected methods of clinical chemistry. Faulkner, W. S., Meites, S. Editors. Washington, DC. American Association for Clinical Chemistry.

Ranjhan, S. K. 2001. Animal nutrition in the tropics. Fifth revised edition. Vikas publishing house PVT Ltd Delhi, India. Pp 210 - 214.

Rej, R. and Hodder, M. 1983. Aspartate transaminase. In: Methods of enzymatic analysis. $3^{\text {rd }}$ Edition. (Begmeryer, H. U. and Grassi, M. Editors). Weinhim Verlag-Chemie. $3: 416-433$.

SAS 1999. Statistical Analysis System, SAS/STAT User's guide, SAS Institute Inc. Cary, North Carolina, USA.
Schalm, N., Jain, N. C. and Caroll, E. J. 1975. Veterinary Haematology. 3rd edition. Lea and Febiger, Philadelphia. U.S.A.;15 - 18.

Stanton, T. B. 2013. A call for antibiotic alternative research. Trends in Microbiology 21: 111-113.

Tisdale, S. L. 1977. Sulphur in forage quality and ruminant nutrition. The Sulphur Institute, Technical bulletin number $22.5-8 \mathrm{p}$

Toro, G. and Ackermann, P. G. 1975. Practical Clinical Chemistry $1^{\text {st }}$ edu. (G. Toro and P. G. Ackermann, Eds). Little Brown and Co. Inc. Bostson, U.S.A.

Van Soest, P., Robertson, J. B. and Lewis, B. A. 1991. Methods for dietary fibre, neutral detergent fibre as nonstarch polysaccharides in relation to animal nutrition. Journal of Dairy Science 74: 3583-3597.

Vihan, V. S. and Rai, T. K. 1987. Certain hematological and biochemical attributes during pregnancy, parturition and post-parturition in sheep and goats. Ind. J. Anim. Sci. 57: 1200-1204.

Received: $15^{\text {th }}$ July, 2016 Accepted: $14^{\text {th }}$ December, 2016 